\title{
EKSPERIMENTASI MODEL PEMBELAJARAN KOOPERATIF TIPE TEAMS GAMES TOURNAMENT (TGT) DENGAN TEKNIK KANCING GEMERINCING PADA POKOK BAHASAN BANGUN RUANG SISI DATAR DITINJAU DARI KEMAMPUAN KOMUNIKASI MATEMATIS SISWA KELAS VIII SMP NEGERI SE-KABUPATEN WONOGIRI TAHUN PELAJARAN 2013/2014
}

\author{
AnnisaSwastika ${ }^{1}$, Mardiyana $^{2}$, SriSubanti $^{3}$ \\ ${ }^{1,23}$ Prodi Magister Pendidikan Matematika, PPs Universitas Sebelas Maret Surakarta
}

\begin{abstract}
The aim of this research was to reveal the effect of TGT cooperative learning model with talking chips technique, TGT cooperative learning model, and direct learning model to the mathematics achievement in polyhedron subject viewed from mathematics communication ability. The type of this research was a quasi-experimental by $3 \times 3$ factorial design. The population was the eighth grade of Junior High School students at Wonogiri regency on academic year 2013/2014. The sample was taken by using stratified cluster random sampling technique. The instruments used for collecting data were mathematics achievement test and mathematics communication ability test. Analysis of the data used was unbalanced two-way analysis of variance. The conclusion of this research shows that TGT cooperative learning model with talking chips technique gives the same achievement as TGT cooperative learning model, but gives better achievement than direct instruction model, and TGT cooperative learning model gives better achievement than direct instruction model. It shows the same result in each categories of mathematics communication ability. Another conclusion shows that students with high mathematics communication ability have the same achievement as students with middle mathematics communication ability but they have better achievement than students with low mathematics communication ability, and students with middle mathematics communication ability have better achievement than students with low mathematics communication ability. It shows the same result in each learning model.
\end{abstract}

Key words: TGT, Talking Chips, and mathematics communication ability

\section{PENDAHULUAN}

Matematika merupakan salah satu cabang ilmu pengetahuan yang mendasari perkembangan teknologi modern. Matematika menjadi alat penting hampir di setiap bidang ilmu pengetahuan dan teknologi. Alasan tersebut menjadi dasar pentingnya penguasaan terhadap matematika sejak dini. Upaya penguasaan terhadap matematika sejak dini telah dilakukan di Indonesia dengan memasukkan matematika sebagai mata pelajaran wajib pada pendidikan formal di tingkat pendidikan Sekolah Dasar.

Berdasarkan pemaparan tersebut, pada tingkat Sekolah Menengah Pertama (SMP), matematika bukanlah mata pelajaran baru tetapi matematika merupakan pengembangan dari materi yang diperoleh di tingkat SD. Penguasaan terhadap matematika merupakan hal yang penting sebagai dasar penguasaan materi di tingkat 
pendidikan selanjutnya. Akan tetapi, fakta yang diperoleh dari Badan Standar Nasional Pendidikan (BSNP) (2013) bahwa rata-rata nilai Ujian Nasional (UN) matematika tahun pelajaran 2012/2013 tingkat nasional sebesar 5,74. Angka tersebut mengalami penurunan dari rata-rata nilai UN matematika tahun sebelumnya, yang diperoleh dari BSNP (2012), yaitu sebesar 7,56.

Rata-rata nilai UN matematika tingkat nasional diperoleh dari rata-rata nilai UN matematika 33 provinsi di Indonesia. Jika dilihat secara nasional, rata-rata nilai UN matematika di Provinsi Jawa Tengah sebesar 5,28 menempati urutan ke-23 dari 33 provinsi di Indonesia, artinya Provinsi Jawa Tengah tidak berada dalam urutan 10 besar untuk rata-rata nilai UN matematika secara nasional. Hal ini menunjukkan masih rendahnya hasil belajar matematika di Provinsi Jawa Tengah. Data dari BSNP (2013), rata-rata nilai UN matematika di Kabupaten Wonogiri sebesar 5,14, masih berada di bawah rata-rata nilai UN Provinsi Jawa Tengah. Selain itu, persentase penguasaan materi bangun ruang di Kabupaten Wonogiri masih rendah dibandingkan dengan persentase penguasaan materi matematika yang lain, yaitu 44,48\%. Hal ini menunjukkan bahwa hasil belajar matematika khusunya pada materi bangun ruang di Kabupaten Wonogiri masih rendah.

Salah satu faktor yang mempengaruhi hasil belajar matematika adalah sikap siswa terhadap matematika. Savas, et al. (2010) menyatakan bahwa "It can be found that the relationship between attitudes toward mathematics and achievement is significant. In other words, it can be said that students who have positive perceptions or attitudes towards mathematics showed better achievement in mathematics". Selain itu, terdapat beberapa hal yang sering dilakukan guru dalam proses pembelajaran sehingga menimbulkan suasana yang tidak kondusif (Hamruni, 2012: 32), diantaranya guru tidak mengajak siswa untuk berpikir sehingga komunikasi hanya terjadi satu arah dan guru tidak mencari penyebab siswa tidak tertarik dengan pembelajaran.

Adanya persepsi negatif siswa terhadap matematika dan suasana yang tidak kondusif dalam pembelajaran berpengaruh terhadap hasil belajar siswa. Dengan pandangan negatif itulah matematika menjadi pelajaran paling sulit dibandingkan mata pelajaran yang lain. Oleh karena itu, kesiapan siswa, kesiapan guru, dan metode penyajiannya harus diperhatikan dalam pembelajaran. Salah satu faktor yang disoroti terkait dengan rendahnya hasil belajar matematika adalah model pembelajaran yang digunakan guru dalam pembelajaran.

Model pembelajaran kooperatif merupakan salah satu bentuk pembelajaran yang berdasarkan paham konstruktivis (Mohammad Jauhar, 2011:52), dimana siswa belajar 
bersama dalam kelompok-kelompok kecil yang saling membantu satu sama lain (Thompson dalam Mohammad Jauhar, 2011:53). Dalam model pembelajaran kooperatif, siswa dikelompokkan secara heterogen berdasarkan kemampuan, jenis kelamin, suku, dan lain-lain. Penelitian yang dilakukan oleh Hossain, et al. (2012) menyatakan bahwa model pembelajaran kooperatif, dimana siswa bekerja sama dalam kelompok kecil untuk mencapai tujuan pembelajaran, memberikan dampak positif terhadap pendidikan matematika dan kemampuan berkomunikasi siswa. Hasil yang sama ditemukan oleh Zakaria, et al. (2013), menyatakan bahwa pembelajaran kooperatif dapat meningkatkan hasil belajar matematika, pemahaman materi, dan rasa percaya diri siswa.

Salah satu model pembelajaran kooperatif yang didalamnya terdapat unsur permainan akademik adalah model pembelajaraan kooperatif tipe TGT. Dengan adanya unsur permainan yang dirancang dalam model pembelajaran kooperatif tipe TGT, diharapkan siswa dapat belajar lebih rileks (Mohammad Jauhar, 2011:62). Model pembelajaran kooperatif tipe TGT mempunyai kemiripan dengan STAD tetapi menggantikan kuis dengan turnamen di akhir minggu atau akhir pokok bahasan, dimana siswa memainkan game akademik dengan anggota tim lain untuk menyumbangkan poin bagi skor timnya (Slavin, 2008:13).

Seperti pada umumnya yang terjadi dalam pembelajaran dalam kelompok, diskusi hanya didominasi oleh beberapa orang anggota kelompok saja sehingga dimungkinkan ada anggota kelompok yang pasif dalam diskusi. Hal ini didukung dengan penelitian Anna Setyowati (2013) bahwa pembelajaran Fan-N-Pick memberikan hasil belajar yang lebih baik dibandingkan dengan model pembelajaran kooperatif tipe TGT. Dalam pembelajaran Fan-N-Pick, siswa mendapat giliran sama dan mempunyai tugas yang berbeda-beda sehingga diharapkan siswa akan dapat membangun pengetahuan dan mengaplikasikannya. Hal tersebut menunjukkan masih adanya kelemahan pada penerapan model pembelajaran kooperatif tipe TGT dimana siswa belum optimal dalam diskusi kelompok dan tidak semua siswa aktif dalam diskusi.

Dengan adanya kondisi tersebut, maka peneliti tertarik untuk melakukan eksperimentasi dengan memodifikasi model pembelajaran TGT dengan teknik kancing gemerincing. Teknik kancing gemerincing merupakan pengembangan dari strategi belajar talking chips yang ditemukan oleh Kagan. Setiap anggota kelompok mendapatkan kesempatan untuk memberikan kontribusi dalam diskusi dan mendengarkan pemikiran anggota yang lain. Teknik ini dapat diterapkan dalam semua mata pelajaran dan semua tingkatan usia anak didik (Anita Lie, 2002:62). Penelitian yang dilakukan oleh Arif Budi Yanda (2013) menyebutkan bahwa teknik kancing gemerincing (talking chip) secara 
signifikan berpengaruh positif terhadap hasil belajar siswa. Oleh karena itu, dengan menggunakan teknik kancing gemerincing, diharapkan setiap siswa lebih aktif dalam diskusi kelompok yang merupakan salah satu komponen penting dalam model pembelajaran kooperatif tipe TGT.

Faktor lain yang kemungkinan berperan dalam hasil belajar siswa adalah kemampuan komunikasi matematis. Komunikasi matematis merupakan cara berbagi ide dan memperjelas pemahaman dalam matematika (NCTM, 2000). Kemampuan komunikasi matematis perlu menjadi perhatian guru sebagai salah satu faktor tercapainya hasil belajar yang optimal. Untuk memahami ide-ide matematika secara benar dan menyampaikan ide-ide tersebut diperlukan kemampuan komunikasi matematis. Jika kemampuan komunikasi lemah, maka akan berakibat pada lemahnya kemampuan matematika yang lain.

Sam \& Meng (2007) menyatakan pentingnya komunikasi matematis dalam pembelajaran matematika karena melalui komunikasi yang efektif siswa mampu untuk mengorganisasikan dan menyampaikan ide-ide kepada guru, teman, dan lainnya. Di samping itu, siswa diharapkan mampu menganalisis dan mengevaluasi pemikiran matematika. Penelitian yang dilakukan oleh Kosko \& Wilkins (2010) menunjukkan bahwa terdapat hubungan yang signifikan antara komunikasi matematis tertulis dan lisan pada siswa. Oleh karena itu, proses pembelajaran matematika yang berlangsung di sekolah hendaknya memperhatikan kemampuan komunikasi matematis siswa.

Berdasarkan uraian yang dikemukakan, tujuan dalam penelitian ini adalah untuk mengetahui: 1) manakah yang memberikan hasil belajar lebih baik diantara model pembelajaran kooperatif tipe TGT dengan teknik kancing gemerincing, model pembelajaran kooperatif tipe TGT, atau model pembelajaran langsung, 2) Siswa dengan kemampuan komunikasi matematis manakah yang mempunyai hasil belajar lebih baik, antara siswa dengan kemampuan komunikasi matematis tinggi, siswa dengan kemampuan komunikasi matematis sedang, atau siswa dengan kemampuan komunikasi matematis rendah, 3) pada masing-masing model pembelajaran, siswa dengan kategori kemampuan komunikasi matematis manakah yang mempunyai hasil belajar lebih baik, antara siswa dengan kemampuan komunikasi matematis tinggi, siswa dengan kemampuan komunikasi matematis sedang, atau siswa dengan kemampuan komunikasi matematis rendah, 4) pada masing-masing kategori kemampuan komunikasi matematis, model pembelajaran manakah yang memberikan hasil belajar lebih baik di antara model pembelajaran kooperatif tipe TGT dengan teknik kancing gemerincing, model pembelajaran kooperatif tipe TGT, atau model pembelajaran langsung. 


\section{METODE PENELITIAN}

Penelitian ini dilaksanakan di SMP Negeri se-Kabupaten Wonogiri dengan subjek penelitian siswa kelas VIII semester II tahun pelajaran 2013/2014. Populasi dalam penelitian ini adalah seluruh siswa kelas VIII SMP Negeri se-Kabupaten Wonogiri. Sampel diambil dari populasi dengan teknik stratified cluster random sampling. Berdasarkan teknik pengambilan sampel tersebut, terpilih 3 sekolah sebagai sampel penelitian yaitu SMP Negeri 1 Baturetno, SMP Negeri 2 Giritontro, dan SMP Negeri 3 Baturetno. Penelitian ini merupakan penelitian eksperimental semu dengan menggunakan rancangan faktorial 3x3 yang digambarkan seperti pada Tabel 1 .

Tabel 1. Rancangan Penelitian

\begin{tabular}{cccc}
\hline $\begin{array}{c}\text { Kemampuan Komunikasi } \\
\text { Matematis }(B)\end{array}$ & Tinggi $\left(b_{1}\right)$ & Sedang $\left(b_{2}\right)$ & Rendah $\left(b_{3}\right)$ \\
$\begin{array}{c}\text { Model } \\
\text { Pembelajaran }(A)\end{array}$ & $(a b)_{11}$ & $(a b)_{12}$ & $(a b)_{13}$ \\
\hline TGT - KG $\left(a_{1}\right)$ & $(a b)_{21}$ & $(a b)_{22}$ & $(a b)_{23}$ \\
TGT $\left(a_{2}\right)$ & $(a b)_{31}$ & $(a b)_{32}$ & $(a b)_{33}$ \\
Langsung $\left(a_{3}\right)$ & &
\end{tabular}

Variabel terikat dalam penelitian ini adalah hasil belajar matematika, sedangkan variabel bebas adalah model pembelajaran dan kemampuan komunikasi matematis. Metode yang digunakan untuk mengumpulkan data adalah metode dokumentasi dan metode tes. Metode dokumentasi digunakan untuk memperoleh data kemampuan awal siswa berupa nilai matematika Ujian Akhir Semester I tahun pelajaran 2013/2014, yang selanjutnya digunakan untuk uji keseimbangan. Metode tes digunakan untuk mengumpulkan data hasil belajar matematika siswa pada materi bangun ruang sisi datar dan kemampuan komunikasi matematis siswa.

Sebelum penelitian, dilakukan uji keseimbangan pada masing-masing populasi untuk mengetahui apakah populasi eksperimen 1, populasi eksperimen 2, dan populasi kontrol dalam keadaan seimbang atau tidak sebelum dikenakan suatu perlakuan. Uji keseimbangan dalam penelitian ini menggunakan analisis variansi (anava) satu jalan dengan sel tak sama. Sebelum dilakukan uji keseimbangan, terlebih dahulu dilakukan uji normalitas dan homogenitas terhadap data kemampuan awal siswa. Selanjutnya, teknik analisis data yang digunakan untuk menguji hipotesis dalam penelitian ini adalah anava dua jalan dengan sel tak sama. Karena uji hipotesis menggunakan anava dua jalan dengan sel tak sama, maka haruslah data hasil belajar sampel memenuhi uji normalitas dan uji homogenitas. 


\section{HASIL PENELITIAN DAN PEMBAHASAN}

Hasil uji keseimbangan terhadap data kemampuan awal siswa diperoleh bahwa ketiga populasi mempunyai kemampuan awal yang sama. Setelah eksperimen, dilakukan pengujian hipotesis dengan menggunakan analisis variansi dua jalan dengan sel tak sama yang dirangkum dalam Tabel 2.

Tabel 2. Rangkuman Hasil Analisis variansi Dua Jalan dengan Sel Tak Sama

\begin{tabular}{ccccccc}
\hline Sumber & $\mathrm{JK}$ & $\mathrm{dk}$ & $\mathrm{RK}$ & $\mathrm{F}_{\mathrm{obs}}$ & $\mathrm{F}_{\alpha}$ & Keputusan \\
\hline Model Pembelajaran (A) & 11546,928 & 2 & 5773,464 & 30,360 & 3,031 & $H_{0}$ ditolak \\
Kemampuan Komunikasi & 2887,549 & 2 & 1443,775 & 7,592 & 3,031 & $H_{0}$ ditolak \\
Matematis (B) & 278,940 & 4 & 69,735 & 0,367 & 2,406 & $H_{0}$ diterima \\
Interaksi (AB) & 49253,735 & 259 & 190,169 & - & - & - \\
Galat & 63967,152 & 267 & - & - & - & - \\
Total & & & & &
\end{tabular}

Berdasarkan Tabel 2, dapat disimpulkan bahwa: (1) model pembelajaran TGTKG, TGT, dan langsung memberikan efek yang berbeda terhadap hasil belajar siswa, (2) kemampuan komunikasi matematis tinggi, sedang, dan rendah memberikan efek yang berbeda terhadap hasil belajar siswa, (3) tidak terdapat interaksi antara model pembelajaran dan kemampuan komunikasi matematis siswa terhadap hasil belajar siswa. Berikut ini disajikan rangkuman rerata sel dan rerata marginal dalam Tabel 3.

Tabel 3.Rangkuman Rerata Sel dan Rerata Marginal

\begin{tabular}{|c|c|c|c|c|}
\hline \multirow{2}{*}{ Model Pembelajaran } & \multicolumn{3}{|c|}{ Kemampuan Komunikasi Matematis } & \multirow{2}{*}{$\begin{array}{c}\text { Rerata } \\
\text { Marginal }\end{array}$} \\
\hline & Tinggi & Sedang & Rendah & \\
\hline TGT $-\mathrm{KG}$ & 76,10 & 73,38 & 67,13 & 72,99 \\
\hline TGT & 76,00 & 71,39 & 65,48 & 71,10 \\
\hline Langsung & 59,27 & 58,44 & 54,63 & 57,29 \\
\hline Rerata Marginal & 72,00 & 67,03 & 61,71 & \\
\hline
\end{tabular}

Dari hasil perhitungan anava diperoleh bahwa $H_{0 A}$ ditolak, artinya terdapat perbedaan efek baris yaitu model pembelajaran terhadap hasil belajar matematika. Oleh karena itu, perlu dilakukan uji komparasi rerata antar baris. Rangkuman hasil uji komparasi rerata antar baris disajikan dalam Tabel 4.

Tabel 4.Rangkuman Hasil Uji Komparasi Rerata Antar Baris

\begin{tabular}{ccccc}
\hline$H_{0}$ & $H_{1}$ & $F_{\text {obs }}$ & $F_{\text {tabel }}$ & Keputusan Uji \\
\hline$\mu_{1 \bullet}=\mu_{2 \bullet}$ & $\mu_{1 \bullet} \neq \mu_{2 \bullet}$ & 0,834 & 6,062 & $H_{0}$ diterima \\
$\mu_{1 \bullet}=\mu_{3 \bullet}$ & $\mu_{1 \bullet} \neq \mu_{\bullet 3}$ & 58,001 & 6,062 & $H_{0}$ ditolak \\
$\mu_{2 \bullet}=\mu_{3 \bullet}$ & $\mu_{2 \bullet} \neq \mu_{3 \bullet}$ & 44,892 & 6,062 & $H_{0}$ ditolak \\
\hline
\end{tabular}

Berdasarkan Tabel 4 dan rerata marginal pada Tabel 3, dapat disimpulkan bahwa model pembelajaran TGT-KG memberikan hasil belajar yang sama baiknya dengan model pembelajaran TGT. Hal ini dimungkinkan karena pada saat pelaksanaan model 
pembelajaran TGT modifikasi teknik kancing gemerincing, dimana siswa diberikan beberapa batang es krim sebagai media interaksi dalam diskusi kelompok, masih ditemukan siswa yang kurang aktif dalam berpendapat sekalipun guru sudah memotivasi dan mendorong siswa untuk aktif dalam diskusi. Sedangkan model pembelajaran TGTKG memberikan hasil belajar lebih baik dibandingkan dengan model pembelajaran langsung. Selain itu, model pembelajaran TGT memberikan hasil belajar lebih baik dibandingkan dengan model pembelajaran langsung. Hal ini dimungkinkan karena dalam model pembelajaran TGT melibatkan siswa aktif dalam pembelajaran, berbeda dengan model pembelajaran langsung yang dilakukan secara tatap muka dengan pemberian instruksi-instruksi dan tugas kepada siswa (Corno \& Snow dalam Magliaro, et al. (2005)). Kesimpulan ini juga sejalan dengan hasil penelitian yang dilakukan oleh Mirawati (2010) bahwa model pembelajaran TGT memberikan hasil belajar lebih baik dibandingkan model pembelajaran langsung.

Dari hasil perhitungan anava diperoleh bahwa $H_{0 B}$ ditolak, artinya terdapat perbedaan efek kolom yaitu kemampuan komunikasi matematis terhadap hasil belajar matematika. Oleh karena itu, perlu dilakukan uji komparasi rerata antar kolom. Rangkuman hasil uji komparasi rerata antar kolom disajikan dalam Tabel 5.

Tabel 5. Rangkuman Hasil Uji Komparasi Rerata Antar Kolom

\begin{tabular}{ccccc}
\hline $\boldsymbol{H}_{\boldsymbol{0}}$ & $H_{1}$ & $F_{\text {obs }}$ & $F_{\text {tabel }}$ & Keputusan Uji \\
\hline$\mu_{.1}=\mu_{.2}$ & $\mu_{\cdot 1} \neq \mu_{\cdot 2}$ & 6,033 & 6,062 & $H_{0}$ diterima \\
$\mu_{\cdot 1}=\mu_{\cdot 3}$ & $\mu_{\cdot 1} \neq \mu_{\cdot 3}$ & 24,028 & 6,062 & $H_{0}$ ditolak \\
$\mu_{\cdot 2}=\mu_{\cdot 3}$ & $\mu_{\cdot 2} \neq \mu_{\cdot 3}$ & 6,561 & 6,062 & $H_{0}$ ditolak \\
\hline
\end{tabular}

Berdasarkan Tabel 5 dan rerata marginal pada Tabel 3, dapat disimpulkan bahwa siswa dengan kemampuan komunikasi matematis tinggi dan sedang mempunyai hasil belajar yang lebih baik dibandingkan siswa dengan kemampuan komunikasi matematis rendah. Kesimpulan ini didukung dengan hasil penelitian Jamilah (2013) menyatakan bahwa hasil belajar siswa dengan kemampuan komunikasi matematis tinggi dan sedang lebih baik dibandingkan siswa dengan kemampuan komunikasi matematis rendah. Sedangkan siswa dengan kemampuan komunikasi matematis tinggi memiliki hasil belajar yang sama baiknya dengan siswa yang memiliki kemampuan komunikasi matematis sedang. Hal ini terjadi dimungkinkan karena materi bangun ruang pernah dipelajari pada tingkatan Sekolah Dasar sehingga siswa dengan kemampuan komunikasi matematis tinggi dan sedang memiliki kemampuan yang relatif sama dalam menyajikan 
permasalahan ke dalam bentuk gambar atau simbol, serta menyatakan model matematika berupa simbol atau gambar ke dalam ide matematika.

Dari hasil perhitungan anava diperoleh bahwa $H_{0 A B}$ diterima, artinya tidak terdapat interaksi antara model pembelajaran dan kemampuan komunikasi matematis. Dengan kata lain, tidak ada ketergantungan antara model pembelajaran dengan kemampuan komunikasi matematis siswa dalam mempengaruhi hasil belajar matematika. Oleh karena itu, tidak perlu dilakukan uji komparasi rerata antar sel pada baris dan kolom yang sama.

\section{SIMPULAN DAN SARAN}

Berdasarkan hasil analisis data dan pembahasan, dapat disimpulkan bahwa (1) model pembelajaran TGT-KG memberikan hasil belajar yang sama baiknya dengan model pembelajaran TGT, sedangkan model pembelajaran TGT-KG dan model pembelajaran TGT memberikan hasil belajar lebih baik dibandingkan model pembelajaran langsung, (2) siswa dengan kemampuan komunikasi matematis tinggi memperoleh hasil belajar yang sama baiknya dengan siswa yang memiliki kemampuan komunikasi matematis sedang, sedangkan siswa dengan kemampuan komunikasi matematis tinggi dan sedang memperoleh hasil belajar lebih baik dibandingkan siswa dengan kemampuan komunikasi matematis rendah, (3) pada masing-masing model pembelajaran, siswa dengan kemampuan komunikasi matematis tinggi memperoleh hasil belajar yang sama baiknya dengan siswa yang memiliki kemampuan komunikasi matematis sedang, sedangkan siswa dengan kemampuan komunikasi matematis tinggi dan sedang memperoleh hasil belajar lebih baik dibandingkan siswa dengan kemampuan komunikasi matematis rendah, (4) pada masing-masing kategori kemampuan komunikasi matematis, model pembelajaran TGT-KG memberikan hasil belajar yang sama baiknya dengan model pembelajaran TGT, sedangkan model pembelajaran TGT-KG dan model pembelajaran TGT memberikan hasil belajar lebih baik dibandingkan model pembelajaran langsung.

Berdasarkan simpulan tersebut, dikemukakan beberapa saran yaitu bagi guru hendaknya dapat menerapkan model pembelajaran TGT-KG sebagai alternatif model pembelajaran khususnya ketika menyampaikan materi bangun ruang sisi datar. Bagi siswa, dengan diterapkannya model pembelajaran TGT maupun TGT - KG dapat membuka pikiran siswa bahwa belajar dapat dilakukan melalui diskusi dengan teman sehingga siswa akan saling membantu memahami materi, dapat mengasah kemampuan berpendapat, dan juga belajar mendengarkan pendapat orang lain. Sedangkan bagi 
peneliti selanjutnya, penulis berharap agar para peneliti selanjutnya dapat meneruskan atau mengembangkan penelitian ini dengan model pembelajaran yang lain atau dengan modifikasi lain dengan memperhatikan pendekatan-pendekatan pembelajaran yang tertuang dalam kurikulum 2013.

\section{DAFTAR PUSTAKA}

Anita Lie. 2002. Cooperative Learning Mempraktikkan Cooperative Learning di Ruangruang Kelas. Jakarta: Grasindo.

Anna Setyowati. 2013. Eksperimentasi Model Pembelajaran Kooperatif Tipe TGT dan Fan -N - Pick pada Prestasi Belajar Matematika Siswa SMP Negeri di Kabupaten Magelang. Tesis. Tidak Diterbitkan. Surakarta: UNS.

Arif Budi Yanda. 2013. Pengaruh Penggunaan Teknik Talking Chip Terhadap Hasil Belajar IPA Fisika Siswa Kelas VII SMPN 1 IV Jurai Kabupaten Pesisir Selatan. Pillar of Physics Education. 1: 97-103

Badan Standar Nasional Pendidikan (BSNP). 2012. Laporan Hasil Ujian Nasional Tahun Pelajaran 2011/2012 SMP/MTs.

Badan Standar Nasional Pendidikan (BSNP). 2013. Laporan Hasil Ujian Nasional Tahun Pelajaran 2012/2013 SMP/MTs.

Hamruni. 2012. Strategi Pembelajaran. Yogyakarta: Insan Madani.

Hossain, A., Tarmizi, R.A., and Ayub, A.F.M. 2012. Collaborative and Cooperative Learning in Malaysian Mathematics Education. IndoMS. J.M.E, 3(2): 103-114.

Kosko, K.W. and Wilkins, J. L. M. 2010. Mathematical Communication and Its Relation to the Frequency of Manipulative Use. International Electronic Journal of Mathematics Education. 5(2): 79-90.

Jamilah. 2013. Eksperimentasi Pendekatan Pendidikan Matematika Realistik (PMR) dengan Metode Discovery Learning pada Materi Pokok Bentuk Aljabar Ditinjau dari Kemampuan Komunikasi Matematis. Tesis. Tidak Diterbitkan. Surakarta: UNS.

Magliaro, S.G., Lockee, B.B., and Burton, J.K. 2005. Direct Instruction Revisited: A Key Model for Instructional Technology. ETR\&D. 53(4): 41-55.

Mirawati. 2010. Eksperimentasi Pembelajaran Matematika dengan Model Pembelajaran Kooperatif Tipe Teams Games Tournament (TGT) pada Materi Pokok Persamaan dan Pertidaksamaan Kuadrat Ditinjau dari Kreativitas Belajar Peserta Didik Kelas X SMA Kotawaringin Timur Tahun Pelajaran 2009/2010. Tesis. Tidak Diterbitkan. Surakarta: UNS.

Mohammad Jauhar. 2011. Implementasi PAIKEM dari Behavioristik sampai Konstruktivistik. Jakarta: Prestasi Pustakaraya. 
National Council of Teachers of Mathematics (NCTM). 2000. Principles and Standards for School Mathematics. The United State.

Sam, L.C. and Meng, C.C. 2007. Mathematical Communication in Malaysian Bilingual Classrooms. Dipresentasikan pada APEC-Tsukuba International Conference di Jepang.

Savas, E., Tas, S., and Duru, A. 2010. Factor Affecting Students' Achievement in Mathematics. Inonu University Journal of The Faculty of Education, 11(1): 113-132

Slavin, R.E. 2008. Cooperative Learning : Tesis, Riset, dan Praktik. Bandung: Nusa Media.

Zakaria, E., Solfitri, T., Daud, Y., and Abidin, Z.Z. 2013. Effect of Cooperative Learning on Secondary School Students' Mathematics Achievement. Journal of Scientific Reasearch. 4(2): 98-100. 